\title{
TÜRK BANKACILIK SEKTÖRÜNDE BIIREYSEL BANKACILIK UYGULAMALARININ SÜRDÜRÜLEBİLİR REKABET ÜSTÜNLÜĞÜ AÇISINDAN DEĞERLENDİRİLMESİ
}

\author{
Berrin ÇAĞLAYAN * i \\ Dr. Öğr. Üyesi Eren DURMUŞ-ÖZDEMIR*
}

\begin{abstract}
ÖZ
Bu çalışmanın amacı, Türk bankacılık sektöründe faaliyet gösteren bankaların bireysel bankacıllk uygulamalarl, rekabet stratejisi ve işletme performansı arasındaki ilişkilerin incelenmesi olarak belirlenmiştir. Araştırma soruları bankaların üst düzey yöneticileri ile derinlemesine yüz yüze görüş̧meler ve destekleyici soru formları yoluyla sorgulanmıştır. Veri seti içerik analizi ile yorumlanmıştır. Bulgular bankaların performanslarını arttıran rekabet stratejilerinin sıraslyla fiyat farklılaştırma stratejisi (özel ürün fiyatlandırma uygulamaları), imaj farklılaştırma stratejisi (pazarlama yeniliğine yönelik uygulamalar) ve kalite farklılaştırma stratejisi (süreç yeniliğine yönelik uygulamalar) olduğunu göstermiștir. Ayrıca bulgular kamu sermayeli bankalar haricindeki diğer bankaların düşük maliyetli operasyonel faaliyetleri ile performanslarını arttırdı̆ğna dair bilgiler de sunmuş̧tur.
\end{abstract}

Anahtar Kelimeler Bireysel Bankacıllk Uygulamalarl, Rekabet Stratejileri, Sürdürülebilir Rekabet

JEL Kodları: M1,M21, M3

\section{EVALUATION OF RETAIL BANKING PRACTICES ON THE SUSTAINABLE COMPETITIVE ADVANTAGE IN TERMS OF TURKISH BANKING SECTOR}

\begin{abstract}
The purpose of this study is to examine the relationships among the retail banking services, competitive strategies and performance of the banks operating in the Turkish banking sector. Research questions were explored through in depth interviews with the upper level managers of the banks supplemented by some survey questions. The data set was interpreted by content analysis. The results showed that increasing competitive strategies of the banks were the price differentiation strategy (special product pricing applications), image differentiation strategy (applications for marketing innovation) and quality differentiation strategy (applications for process innovation)

\footnotetext{
* Akdeniz Üniversitesi Sosyal Bilimler Enstitüsü İşletme ABD, Antalya.brn_caglayan@hotmail.com

* Akdeniz Üniversitesi İİBF İşletme Bölümü, Antalya. edurmus@akdeniz.edu.tr
} 
respectively. In addition, the findings submit also information with increasing performance of low-cost operational activities in other banks than the public banks.

Keywords: Retail Banking Practices, Competitive Strategies, Sustainable Competitive.

JEL Codes: $M 1, M 21, M 3$

\section{GİRIŞ}

1980'li yıllardan itibaren otomasyonun Türk bankalarının gündeminde yer edinmesiyle birlikte bireysel bankacılık uygulamaları sektörde önemli bir rekabet aracı olarak dikkat çekmeye başlamıştır. Özellikle XXI. yüzyılda tüm dünyada finansal piyasalardaki teknolojik gelişmelerin Türkiye'yi de etkilemesi bankaların farklı bireysel bankacılık uygulamaları ile rekabet etmesine neden olmuştur. Tüketici istek ve beklentilerindeki gelişmeler ve sürekli değişen mevzuatlar bu hizmet ve ürünlerin sunulmasında kamu, özel ve yabancı sermayeli bankalar arasında farklılık yaratarak rekabeti yoğunlaştırmıştır. Artık bankalar bireysel bankacılığa dair yenilikçi uygulamalar ile yüksek maliyetli şube bankacılığı yerine daha düşük maliyetle aynı işlemleri yapabilen otomasyona dayalı bireysel bankacılık sistemlerini tercih ederek ortalama üzerinde getiri elde etme çabasına girmişlerdir.

Küresel ekonomik sistemin lokomotifi olan bankaların bireysel bankacılık uygulamalarının sürdürülebilir rekabet üstünlüğüne etkileri ile ilgili tartışmalar devam ederken, akademik yazında konuya olan ilgi de artmıştır. İlgili yazında konuyu farklı yönleri ile inceleyen çok sayıda lisansüstü araştırma ve bilimsel araştırma bulunmasına rağmen bireysel bankacılık uygulamalarının sürdürülebilir rekabet üstünlüğünün genel görünümünü yansıtan detaylı bir çalışmaya rastlanılmamıştır. Ulusal alan yazında konu ile ilgili oldukça sınırlı sayıda araştırma bulunması (Arslan ve Hotamışl1, 2007) rekabet stratejilerinin bireysel bankacılık uygulamaları ile performansa yansıyan sonuçlarına dair araştırma sorusunun önemini ortaya çıkartmıştır. Türkiye'deki bankaların rekabet stratejilerinin bireysel bankacılık hizmetleri açısından ne kadar farklılaştığının önceden kestirilmesinin oldukça zor olması, bilimsel açıdan ölçme ve değerlendirme araçlarının bulunmaması alan yazındaki araştırmaların başlıca sıkıntıları olarak gözlemlenmiştir. Bu nedenle mevcut çalışmada Türk bankacılık sektörünün gelişimindeki bireysel bankacılık uygulamalarına dayalı rekabet dinamiklerinin ortaya çıkartılması ilginç bir araştırma sorusu olarak görülmüştür. Çalışmanın amacı Türk bankacılık sektöründe faaliyet gösteren kamu, özel ve yabancı sermayeli mevduat bankalarının bireysel bankacılık hizmetleri açısından ne tür rekabet stratejileri ile sürdürülebilir rekabet sağladıklarının incelenmesi olarak belirlenmiştir.

\section{BIREYSEL BANKACILIK UYGULAMALARI VE SÜRDÜRÜLEBILIIR REKABET ÜSTÜNLÜĞÜNE GENEL BAKIŞ}

Dünyadaki gelişmelere paralel olarak ülkemizde de bireysel bankacılık uygulamalarının başlangıcı kredi kartları ve ATM'ler ile olmuştur. 1968 yılında Koç grubuna bağlı Setur A.Ş.'nin 
Diners Club'tan yetki alarak ilk kredi kartını hizmete sunması ile başlayan süreç, 80'lerde Mastercard ve Visa kartları ile ödeme sistemlerinin artışı, 1982' de ilk kez İş Bankası tarafından çevrim dışı olarak hayata geçirilen bankamatikleri, “banka garantili çek” sistemi ile günlük ödemelerde çek kullanımı ile hız kazanmıştır (Çırpan, 2000; Muze.isbank.com.tr/,15.03.2018; bkm.com.tr, 05.01.2018). Uygulamalardaki çeşitlilik 1990 yılında 13 kamu ve özel bankanın ortaklığıyla kurulan Bankalararası Kart Merkezi (BKM) ile kurumsal bir yapıya bürünmüştür. Böylece her türlü ödeme ve para transferi güvenli, hızlı ve az maliyetli bir altyapı ile gerçekleştirilmeye başlanmıştır (bkm.com.tr, 05.01.2018). BKM’nin kurulmasının ardından kartlı ödeme sistemindeki büyümenin etkisiyle 1991 yılında satış noktası terminali (POS) hizmeti kullanıma sunulmuş, 1998 yılında ise kart ile taksitli ödemeler, mil ve nakit puan toplama uygulamaları başlatılmış, 2000 yılında BKM ve üye kuruluşlar arasında kişisel tanımlama numarası uygulamasına geçiş kararı ile ilk sanal kredi kartı hayata geçirilmiştir. Aynı yıllarda banka kartlarının alışverişlerde kullanımını yaygınlaştırmak için "Banka Kartı Bilinçlendirme Kampanyası" başlatılmıştır (bkm.com.tr, 05.01.2018). 2008 yılında BKM ve Turkcell işbirliğiyle 3D Secure ve Turkcell mobil imzanın entegrasyonu sağlanarak mobil imza kullanıma sunulmuştur (Haberler.com.tr, 10.02.2008). BKM tarafindan 2012 yılında dünyanın ilk ulusal dijital cüzdanı olan BKM Express uygulaması devreye girmiştir. Çarpıcı önemli gelişmelerden birisi de 2015 yılında BKM ve Türksat'ın hazırladığı alt yapıyla E-devlet kapısı üzerinden ilk defa bankacılık kartları ile Tapu Kadastro Genel Müdürlüğü tapu harcı tahsilâtlarının yapılmaya başlanmış olmasıdır.

Günümüz belirsiz ve dinamik çevre koşulları altında rakipleriyle ve banka dışı finansal kurumlarla sürekli yarış içinde olan bankalar bireysel bankacılık uygulamaları ile sürdürülebilir rekabet üstünlüğünü amaçlar olmuştur. Sürdürülebilir rekabet üstünlüğü (SRÜ) stratejik yönetim alan yazınında konumlandırma okuluna (positioning school) ve kaynaklara dayalı okula (resource based school) göre açıklanmaktadır. Konumlandırma okuluna göre SRÜ işletmenin rakiplerine karşı uzun dönemde rekabet stratejileri ile finansal performansını yüksek tutması olarak tanımlanmaktadır (Porter, 1980). Porter'a (1980, 1985) göre SRÜ’yü sağlamanın yolu maliyet liderliği, farklılaştırma ve odaklanma stratejilerinden geçmektedir. Maliyet liderliği stratejisi işletmenin endüstri içerisinde en düşük maliyetle üreten olmayı hedef olarak seçerek faaliyetlerini rakiplerinden daha az maliyetle gerçekleştirmesidir. Farklılaştırma stratejisi ise işletmenin sunduğu ürün ve hizmetlerde farklılık yaratarak sektör ortalamalarının üzerinde getiri elde etmesini sağlayan bir stratejidir. Farklılaştırma tüketici tercihlerini etkileyerek dikkat çeken ve rekabet avantajı sağlayan bir stratejidir. Farklılaştırmanın kaynağı ürün veya hizmetin yeniliğidir (Porter, 2000). Mintzberg'e (1988) göre farklılaştırma stratejisi fiyat, imaj, destek, kalite ve tasarımdan oluşmaktadır. Fiyat farklılaştırma stratejisi işletmelerin ürün ve/veya hizmetlere ilişkin fiyatlarını, piyasa ortalaması üzerinde ya da üstünde belirlemesidir. İmaj farklılaştırma stratejisi ürün ve/veya hizmete müşteri ihtiyaçlarını karşılama bakımından görünüm ve estetik yönünden değer katılmasıdır. Destek farklılaştırma stratejisi ürün ve/veya hizmetin kendi niteliğinde bir farklılık yaratmaktan çok, müşteriye sunulan destek 
hizmetlerinde bir farklılaşma yapılmasıdır. Kalite farklılaştırma stratejisi ürün ve/veya hizmetin niteliğinde farklılık yapacak ve müşteri için daha cazip hale getirecek her türlü çabanın gerçekleştirilmesidir. Tasarım farklılaştırma stratejisi ise ürün ve/veya hizmetin dış görünüşlerini veya fiziksel konumunu değiştirerek farklı bir ürün/hizmet ortaya konması olarak tanımlanmaktadır.

Stratejik yönetim alan yazınında kaynak temelli okula göre SRÜ, bir işletmenin rakipleri tarafindan taklit edilemeyen ve faydaları kopyalanamayan, değer yaratan stratejiyi uygulaması olarak tanımlamaktadır (Barney, 1986). Barney'e (1991:102) göre işletmeler rakiplerinin taklit etme girişimlerine rağmen hala faaliyetlerine devam ettiği sürece sürdürülebilir rekabet üstünlüğünü sağlamış olacaktır. Sürdürülebilir rekabet üstünlüğünü açıklamada kaynak ve yeteneklerin önemine vurgu yapan kaynak temelli okul ile (Barney, 1986, 1991; Grant, 1991; Amit ve Schoemaker, 1993; Peteraf, 1993; Collis ve Montgomery, 1995) ile sektör yapıs1 ve firma performansı arasında belirleyici ilişki olduğuna vurgu yapan konumlandırma okulu alan yazındaki egemen duruşları ile katkı sağlamaya devam etmektedir. Bu noktadan hareketle mevcut çalışmada iki bakış açısı rekabet üstünlüğünü açıklamada bütünleyici bir yaklaşım olarak ele alınarak bankaların rekabet stratejilerinin performansa yansıyan sonuçları bireysel bankacılık kaynak ve yetenekleri açısından incelenecektir.

\section{ARAŞTIRMA YÖNTEMI}

\subsection{Veri Toplama Süreci}

Araştırmanın kapsamı veri toplama sürecinde nitel yöntemlerin bir arada kullanılmasını gerekli kılmıştır. Nitel araştırma kapsamında görüşme, gözlem ve doküman incelemesinden yararlanılmıştır. Veri toplama aşamasının ilk kısmında araştırma evrenini belirlemek amacıyla Türkiye Bankalar Birliği ve bankaların internet sitelerinden faydalanılmıştır. Sağlanan bilgiler yardımıyla görüşme yapılacak bankalar tespit edilmiştir. Ardından görüşmeyi kabul eden üst düzey yöneticiler ile yarı yapılandırılmış görüşmeler gerçekleştirilmiştir. Tüm görüşmeler Kasım 2016 -Nisan 2018 tarihleri arasında yapılmıştır. Ortalama 60-180 dakika arasında süren görüşmeler kayıt cihazı ya da not alma yöntemi ile kaydedilmiş ve her görüşmeden sonra kayıtlar çözümlenmiş̧ir. Çalışmada görüşme yoluyla elde edilen veriler içerik analizi ile değerlendirilmiştir. Genel olarak objektif bir veri yorumlama yöntemi olarak tanımlanan içerik analizi tüm yazılı kayıtların araştırma problemleri ve amaçlarına göre kodlanması ve çözümlenmesi temeline dayanmaktadır (Berg ve Lune, 2015). Bu çalışmada içerik analizi için mülakat metinlerine ek olarak bankacılık sektöründe sıkça takip edilen dergi ve internet sitelerinden de haberlere ait dokümanlar da kullanılmıştır.

\section{2. Örneklem}

Türkiye' de faaliyet gösteren bankaların sayısına ilişkin bilgiler çeşitli resmi internet sitelerinde yer almaktadır. Bu sitelerde bankaların sayısı farklılık gösterdiğinden gerek bankalar gerekse resmi finansal kuruluşlar tarafindan kabul görmüş bir kaynağa ihtiyaç duyulmuştur. Nihai olarak güncel ve 
güvenilir olması nedeni ile Türkiye Bankalar Birliği’nin (TBB) resmi internet sitesinden yararlanılmıştır. Türkiye Bankalar Birliği'nin "Bankacılık Sisteminde Banka, Çalışan ve Şube Sayıları" raporunun Haziran 2017 verilerine göre 47 banka çalışmanın araştırma evrenini oluşturmuştur. Araştırmanın Antalya ilinde faaliyet gösteren toplam 12 bankanın (3 adet kamu sermayeli, 5 adet özel sermayeli ve 4 adet yabancı sermayeli) (tbb.org.tr, 11.06.2017; bankalar.org.tr, 12.06.2017) bölge müdürlüğü seviyesindeki üst düzey yöneticileri ile yürütülmesi planlanmıştır. Nihai olarak bu çalışma kapsamında görüşme için bilgisine başvurulacak 10 bankanın (3 adet kamu sermayeli banka, 4 adet özel sermayeli banka ve 3 adet yabancı sermayeli banka) 10 üst düzey yöneticisi ile (Bireysel Bankacılık Bölge Yöneticisi, Bölge Satış ve Performans Yetkilisi, Bireysel Portföy Yöneticisi, Bireysel Bankacılık Bölge Satış Yönetmeni vb) görüşmeler yapılmıştır. Araştırmanın veri toplama süreci 2 adımdan oluşmuştur. İlk dönem Kasım 2016- Mart 2017 tarihleri arasında 6 bankanın 6 üst düzey yöneticisi ile Eylül 2017- Nisan 2018 tarihleri arasında da 4 bankanın 4 üst düzey yöneticisi ile görüşme yapılmıştır. Araştırma sürecinin ilk döneminde Çağlayan'ın (2017) "Bireysel Bankacılık Hizmetlerinin Rekabet Stratejileri Açısından İçerik Analizi İle İncelenmesi” başlıklı yayınlanmamış yüksek lisans tezi veri toplama sürecinden faydalanılmıştır. Araştırma sürecinin ikinci döneminde ise mevcut çalışmanın yazarları örneklemde eksik kalan diğer bankaları veri toplama sürecine dahil etmiştir.

Araştırmanın Antalya ilinde yürütülmesinin birkaç gerekçesi bulunmaktadır. Öncelikle çalışma kavramsal açıdan önem taşıyan rekabet stratejilerinin bankacılık sektöründe bireysel bankacılık uygulamaları ile nasıl ilişkilendirildiğinin sorgulanmasını gerekli kıldığından stratejik düzeyde verilen bireysel bankacılık uygulamalarına ilişkin merkezi kararların iller arasında farklılık yaratmadığı belirlenmiştir. Diğer bir gerekçe ise Antalya'nın son yıllarda artan bankacılık ve bireysel bankacılık uygulamaları ile ülke genelinde ekonomik göstergelere önemli katkılar yaratan bir il olarak dikkat çekmesidir. Türkiye Bankalar Birliği’nin "İllere ve Bölgelere Göre Yayınlanmış İstatistikî Rapor" verileri incelendiğinde Antalya ilinin toplam mevduatının yaklaşık 33.746 milyon TL, toplam kredilerinin 59.623 milyon TL, şube başına düşen ortalama mevduatın 79 milyon TL, kredinin ise 140 milyon TL olduğu görülmektedir (tbb.org.tr, 11.06.2017). Ek olarak Antalya ilinde 2017 yıl1 itibari ile toplam banka şube sayısının 428 adet, toplam ATM sayısının 1.942 adet, POS sayısının ise 105.752 adet olduğu belirlenmiştir (tbb.org.tr, 11.06.2017). Bu nedenle araştırma kapsamında Antalya ili sonuçlarının, Türkiye genelinde bankacılık sektöründe bireysel bankacılık uygulamaları açısından anlamlı bir fotoğraf sunacağı düşünülmüştür.

\subsection{Veri Toplama Araçları}

Çalışmada veri toplama araçları olarak yarı yapılandırılmış görüşme formu, gözlem ve dokümanlardan faydalanılmıştır. İlgili yazın incelendiğinde bireysel bankacılık uygulamaları açısından rekabet stratejileri ve performans ilişkisini inceleyen sınırlı sayıda araştırmaya ulaşılmıştır (Arslan, 
2008). Bu nedenle araştırmada kullanılacak görüşme formu araştırmacılar tarafindan geliştirilmiştir. Görüşme formunda işletmelerin stratejilerini belirlemeye yönelik soruların geliştirilmesinde Porter'ın (1980) rekabet stratejilerinin daha geniş sınıflandırmasını yapan Mintzberg'in (1988) kavramsal strateji tipolojisinden faydalanılmıştır. İlgili yazın taraması sonucunda, bu stratejilerin ölçümüne yönelik geçerliliği ve güvenilirliği kabul görmüş Robinson ve Pearce (1988), Dess ve Davis (1984) tarafından geliştirilen özgün ölçeğin Türkçe'ye uyarlanmış haline ulaşılmıştır. Durmuş-Arıcı (2008) tarafından uyarlanan bu ölçeğin geçerliliği ve güvenilirliğinin bulunması ve ülkemizde henüz bireysel bankacılık uygulamalarına özgün benzer bir soru formuna rastlanılmaması nedeniyle mevcut araştırmada bu ölçüm aracından yararlanılmıştır. Araştırmacılar bankacılık sektörüne ve bireysel bankacılık hizmetlerine yönelik ilgili yazında yer alan çalışmalar yardımıyla rekabet stratejileri ölçeğinde yer alan her bir ifadenin karşılığını ifade havuzu haline çevirmiştir. İfade havuzuna dayalı görüşme formunun nihai haline ulaşması için belirli dönem aralıklarında toplam 3 adet pilot çalışma yapılmıştır. Pilot çalışmalar bankacılık sektöründe aktif 5 yöneticinin ve bankacılık/ finans alanında uzman bir öğretim üyesinin görüşleri ve tavsiyeleri yardımıyla gerçekleştirilmiştir. Pilot çalışma neticesinde eksikler belirlenip gerekli düzeltmeler yapılarak rekabet stratejilerine ilişkin soru formu nihai hale getirilmiştir.

Araştırmada bankaların performansının değerlendirilmesinde öznel yönetici değerlendirmelerinden faydalanılmıştır. Stratejik yönetim alanında işletme performansına yönelik araştırmalar öznel yönetici değerlendirmelerinin, işletme dışı kaynaklar tarafından hazırlanan ikincil veriler kadar tutarlı olduğuna işaret etmektedir (Dess ve Robinson, 1984; Conant, Mokwa ve Varadarajan, 1990; Venkatraman ve Ramanujam, 1986). Bu çalışmalarda nesnel ve öznel performans göstergeleri arasında yüksek korelasyon bulunmaktadır. Mevcut tez çalışmasında bankaların performans düzeylerinin belirlenmesinde öznel değerlendirmelerin dikkate alınması uygun görülmüştür. Bu amaçla geçerliliği ve güvenilirliği kanıtlanmış Venkatraman'ın (1989) özgün performans ölçeğinden faydalanılmıştır. Ölçekte yer alan ifadeler bankacılık sektörüne ve bireysel bankacılık hizmetlerine yönelik ilgili yazında yer alan çalışmalar ve pilot çalışmalar revize edilerek nihai hale getirilmiştir.

Görüşme formunda banka yöneticilerine temel başlıklar halinde şu sorular yöneltilmiştir: Bireysel bankacılık faaliyetlerine yönelik maliyetleri düşürme çalışmaları nelerdir; rakiplerine kıyasla bireysel bankacılık faaliyetlerine ilişkin fiyatlandırma politikaları nelerdir; bireysel bankacılık faaliyetlerine yönelik rakiplerinden farklı tanıtım (tutundurma) ve marka faaliyetleri nelerdir; bireysel ürün ve hizmet kalitesi rakiplerine göre farklılık göstermekte midir; fiziksel tasarıma ve teknoloji donanıma (en son teknolojik donanımları dikkate alarak) yönelik faaliyetleri nelerdir; tüm bu faaliyetlerin ayrı ayrı işletme performansına etkisi bulunmakta mıdır? 


\section{BULGULAR}

İçerik analizine göre bulgular bankaların bireysel bankacılık uygulamalarının rekabet stratejisine ve işletme performansına yansıyan sonuçları ile sürdürülebilir rekabette etkili olduğuna işaret etmiştir. Bulgular tüm bankaların bireysel bankacılık uygulamalarına dayalı algılanan performans düzeyini en fazla etkileyen üç rekabet stratejisinin sırasıyla fiyat farklılaştırma stratejisi, imaj farklılaştırma stratejisi ve kalite farklılaştırma stratejisi olduğunu göstermiştir. Ayrıca bulgular kamu sermayeli bankalar haricindeki diğer tüm bankaların düşük maliyetli operasyonel faaliyetleri ile performanslarını arttırdığına dair bilgiler de sunmuştur. Araştırmanın ilk bulgusu görüşme yapılan yöneticilerin tamamının sürdürülebilir rekabette işletme performansını en fazla etkileyen rekabet stratejisinin fìyat farklılaştırma olduğuna yönelik ortak algıları olmuştur. Yöneticiler bireysel bankacılık uygulamalarında müşterinin özelliklerini (örneğin maaş müşterisi, emekli vb.), müşterinin bağl1lık düzeyini (örneğin 5 ylldan fazla müşteri olanlar vb.), müşterinin lokasyonunu ve müşterinin kredibilite oranını (örneğin yüksek puanlı kredi kullananlar vb.) dikkate alarak fiyat farklılaştırma stratejisini uyguladıklarını ve böylece ortalama üzerinde getiri elde ettiklerini belirtmişlerdir. Konu ile ilgili kamu bankası bireysel portföy yöneticisi KB3 kredi notuna ilişkin şu açıklamalarda bulunmuştur: "Kredi notu nedir: Geçmiş kredi ve kredi kartı bilgileriniz göz önünde bulundurularak 0 ile 1400 arasında aldiğınız ortalama puan türüdür. Ĕ̆er müşteri olarak notunuz 1400 üzerindeyse rahatlıkla tüm bankalardan kredi kullanabilirsiniz ve düşük faiz ile kredi alabilirsiniz. 500 puan altındaysanız şansınız oldukça düşüktür. Bu puanlar her banka için önemli. Bizim de yer aldiğımız ve Türkiye'nin önde gelen dokuz bankasının ortaklığı ile kurulan Kredi Kayıt Bürosu tarafindan hayata geçirilen Findeks önemli bir platform. Bu platform bize müşterinin risk raporunu veriyor. Hangi müşteriye hangi düzeyde faiz oranı uyguladiğınız elbette bankalar için oldukça önem taşıyor. Findeks ile yani bireylere ve reel sektöre yönelik olarak tasarlanmıs yeni finansal hizmet platformu BDDK ve bağımsız denetim şirketlerince denetlendiğinden bizim için güvenilir bir kaynaktır. Müşteri olarak bankalardan kullanmış olduğun bireysel nitelikli tüm kredi ve kredi kartı hesaplarının geçmiş verilerin üzerinden değerlendirmesi yapıllyor. Kaçış yok (KB3)". Ayrıca tüm yöneticiler fiyatlandırma politikalarında emeklilere, maaş müş̧terilerine ve personele ürün/hizmet sunumunda özel uygulamalarının önemli bir kaynak olduğunu bu kaynakların ortalama üzerinde getiri yaratarak sürdürülebilir rekabeti sağladıklarını vurgulamıştır. Konu ile ilgili ÖB1 maaş müşterilerinin önemini açıkça şöyle vurgulamıştır: "Çalışstığımız kurumların personeline göre fiyatlandırma politikaları uygulayabiliyoruz. Bu önemli. Çünkü maaş müşterimiz bizim bankamızı evi gibi hissetmeli. Ücretsiz EFT yapabilmeli, faturasını ödeyebilmeli ya da bütçesine uygun tüketici kredisi için faiz oranı alabilmeli. Örneğin; maaş ödemelerini yaptığımız Akdeniz Üniversitesi personelini yıllardır çalıştıkları IB' dan koparabilmek zamanımızı aldı. Ki IB hala eski maaş müşterilerini bazı uygulamalarla elde tutmaya çalışlyor: Ücretsiz havale yaptırlyor, fatura ödemeye ek puan veriyor. Bu bizim bankamızı zorlamıyor. Çünkü esas olan faiz oranı IB olarak ücretiz havale yapıyor olmanız onlara düşük faiz vermenizi 
garanti etmiyorsa, müşsteri hemen tercihini değiştirebiliyor. "Maaşımı TB' dan alyyorum, bana düşük faiz oranı da verdi, sıkıntı olmaz" diyor. Bunu çeşitlendiriyoruz: Anlaştığımız kamu kurumlarının çalışanlarının maaşlarına göre farklı fiyatlandırma uygulanabiliyor. Bu tür uygulamalar ile yıllardır rekabette yer alabiliyoruz (ÖB1)". Fiyat farklılaştırma ve sürdürülebilir rekabet ilişkisine yönelik bir diğer bulgu ise tüm bankaların sürdürülebilir rekabette müşteriye özel fiyatlandırmanın önemli bir yetenek olarak işletme performansına yansıyan olumlu sonuçları olduğudur. Konu ile ilgili olarak KB3 şu açıklamalarda bulunmuştur: "Fiyatlandırmada müşterinin mesleğine göre kamu ya da özel ayrı ayrı değerlendiriyoruz. Yani kamu ve özel maaş müssterilerine göre değişiyor. Kamu personeline özel oranımız her zaman vardır. Yaz döneminde yaz kredisi çıkar. Kredilerimize dönemsel (sonbahar, kış, yaz gibi) faiz oranları uyguluyoruz. Fiyatlandırmada müşterinin puanına göre Genel Müdürlük bazında inceleme yapıllyor. Müşterinin ödeme performansına göre müşterinin çekeceği rakamı sistem belirliyor. Mevduatın büyüklüğüne göre faiz oranları değişiyor. Ürün sahipliğine ve çapraz satışlara göre değissiyor. Promosyon dönemindeyiz emeklilere promosyon veriliyor. Eğer emekli müşterilerimiz isterlerse onlara bu dönemde kredi veriyoruz. Emekli müşterilerimizde yaşs stnırı var. Örneğin 70 yaşın üstünde olanlara en fazla 10 bin veriyoruz. Müşterinin gelir durumu en önemli faktördür. Kampanyaya göre faizlerimiz değişiyor. İsimleri mevsimsel olarak (sonbahar, kış, yaz) düzenleniyor. Nisan ayı bankamızın kuruluş yılıdır. Bu dönemdeki kredi "kuruluş yıl dönümü kredisi” olarak çıkıyor (KB3)".

Araştırmanın ikinci bulgusu görüşsme yapılan yöneticilerin tamamının sürdürülebilir rekabette işletme performansını ikinci etkileyen rekabet stratejisinin imaj farklılaştırma olduğuna yönelik ortak algıları olmuştur. Bulgular imaja yönelik bireysel bankacılık uygulamaları arasında en fazla görsel medya araçlarının (örneğin marka yüzü veya animasyonlar) ve sosyal medya araçlarının (örneğin Twitter, Facebook, İnstagram) önemine işaret etmiştir. Konuyla ilgili kamu sermayeli bankanın bireysel bankacılık bölge yetkilisi KB1 tutundurma faaliyetlerinde televizyon reklamına verdikleri önemi şu cümlelerle vurgulamıştır: "Güçlü bir devlet bankası olarak daha çok televizyon reklamına önem veriyoruz. "Halk ister biz yaparı"” reklam sloganımızı görmüşsünüzdür. Yani önceliğimiz müşterilerimizin istekleridir. Bankamızın diğer rakip bankalar gibi maliyetsiz olan Twitter, Facebook gibi sosyal hesapları da bulunmaktadır. Fakat bankamız işitsel ve görsel açıdan müşteriler üzerinde daha etkili olduğunu düşündüğü televizyon reklamını tercih etmektedir. Çünkü esas olan geniş müşteri kitlesine ulaşmaktır. Bankamı diğer bankalar gibi tanıtım ve marka faaliyetlerinin satışa ve kârlılı̆ga etkisi olduğunu düşünmektedir (KB1)”. Görüşme yapılan diğer kamu sermayeli bankanın bireysel portföy yöneticisi KB3 ise televizyon reklamının özellikle yaş ortalaması yüksek müşterilerde daha etkili olduğu yönündeki açıklaması ise şöyle olmuştur: "Sosyal ağlarda her banka gibi bizim bankamızında gerekli tanıtımı yapılmaktadır. Müşterilerimiz tarafından dijital kanallarımız etkin kullanılmaktadır. Mobil, internet bankacılı̆̆ı gibi dijital kanallara müşterilerimizi yönlendirmeye çalışlyoruz. Yani müşterilerimizi ücretsiz olan sosyal ağlara kullandırmaya kısmen de 
olsa zorluyoruz. Çünkü günümüz teknoloji çağı ve biz bu kanallar aracıllğıyla çok fazla müşteriye ulaştığımızı düşünüyoruz. Fakat emekli müşterilerimizin bu kanalları kullanırken zorlandığını fark ettik. Bu yüzden bankamızın tanıtım faaliyetlerinde televizyon reklamının kullanılmasına karar verdik. Bankamızın maliyetli olmasına rağmen televizyon reklamından kaçışı yoktu. Çünkü biz müşseri memnuniyetine önem veren bir kamu bankasıyı (KB3)". Sosyal ağların sürdürülebilir rekabette olumlu etkisine dikkat çeken ÖB4 bankalarında uygulamış oldukları tutundurma faaliyetlerini şu şekilde özetlemiştir: “Bankaların sosyal medyayı kullanım amaçları elbette performansı yükseltmektir. Performans sadece dönemsel değil uzun vadede sağlandı̆̆ından imajınızı să̆lam tutmanız gerekmektedir. Bu nedenle bizim için tüm sosyal medya araçları önemlidir. Bir müşterinin herhangi bir şikâyet sitesine dahi hakkımızda yazacağı olumsuz ifadelerin bize geri dönüş maliyetleri oldukça yüksektir. Yani her satır, her ifadeyi, hatta her emojiyi dikkate alarak pazarlama yapmak zorundayı. Aksi halde rakiplerin yüzlerini güldürürüz ve devamlılı̆ımızı sonlandırabiliriz (ÖB4)'. Konu ile ilgili yabancı sermayeli bankanın bölge yöneticisi/ satış yöneticisi YB1 bankalarında uygulamış oldukları tutundurma faaliyetlerini şu şekilde özetlemiştir: "Bankaların sosyal medyayı kullanım amaçları ürün/hizmet ve kampanyaları hakkında bilgi vermek, tanıtmak ve müşterileri dinlemektir. Memnuniyetle söylüyorum: Bankamızı Facebook sayfası kampanya ve bilgilendirme mesajların detaylı bir şekilde müşterilerimize iletmemize, yeni reklam videolarını hızlı bir şekilde yaymamıza olanak sağllyor, Twitter ise kullanıcı yorumlarını daha kolay takip etmemizi sağllyor. Bankamızın müşterilerimiz ile sürekli etkileşim içinde olması, müşterilerin şikâyet ve önerilerine kısa sürede dönüş yapması müşteri memnuniyetimizi arttırıyor. Sosyal medyayı müşterilerimize direkt ulaşabilecek bir kanal olarak görüyoruz (YB1)”.

Araştırmanın üçüncü bulgusu görüşme yapılan yöneticilerin tamamının sürdürülebilir rekabette işletme performansını etkileyen son farklılaştırma stratejisinin kalite farklılaştırma olduğu yönündeki algllara sahip olduğudur. Yöneticiler ürün/hizmet sunumunda sürece yönelik yeniliklerle kaliteyi belirli bir seviyede tutma ya da yükseltme çabası içinde olduklarını böylece sürdürülebilir rekabeti sağladıklarını belirtmişlerdir. Özellikle bulgular insan kaynakları sürecinde kalitenin önemine vurgu yapmaktadır. Konu ile ilgili kamu sermayeli bankanın bireysel bankacılık portföy yöneticisi KB3 bankaların bireysel bankacılık uygulamalarında müşteri özelliklerine göre uzman personeli istihdam etmelerinin sürdürülebilir rekabette ortalama üstünde bir getiri elde etmelerine yönelik açıklamalarını şu şekilde aktarmıştır: "Bankaların personeli önemli bir kaynaktır. Bu kaynak ile uzun dönem performansinızı yükseltebilir ya da yerinizde sayabilirsiniz. Bu nedenle bizim personelimizde bölgeye göre istihdam farklılıklarl olabiliyor. Örneğin doğu bölgesinde bazı müşterilerimiz Türkçe konuşmasını bilmiyor. Hatta bankacılık işlemlerimizde örneğin form doldurulurken yazı yazılması gereken durumlarda müşterimiz Türkçe el yazısı yazamıyor. Bu yüzden müşteri potansiyeline göre hareket ederek alanında uzman personelimizi belirli illerdeki şubelere daha özenli yerleştiriyoruz. Çünkü bankamızın müşterimizin dilinden anlayan personele ihtiyacı var 
(KB3)”. Ayrıca araştırmada sürdürülebilir rekabet avantajı sağlamada önemli bir kaynak olarak çeşitli performans sistemleri ile kalitenin yükseldiği böylece performansın da arttırdı̆̆ y yönünde bulgulara rastlanmıştır. Konu ile ilgili yabancı sermayeli bankanın bölge yöneticisi/ satı̧̧ yöneticisi YB1 performans sistemleri ile müşterilerin önerilerini dikkate aldıklarını şöyle açıklamışlardır: "Performans karnesi: kârlılık, verimlilik gibi finansal göstergelerin yanısıra müşteri memnuniyeti, yeni müşteri kazanımı, müşsteri devamlılığl, yeni hizmet/ürün yaratma kabiliyeti, kalite standartları, operasyonel süreçlerin iyileştirilmesi, çalışanların bilgi düzeyleri ve bilgi teknolojilerinin yeterliliği gibi işletmenin güçlü ve zaylf yönlerini ele alan finansal olmayan göstergelerden de oluşan bir yönetim aracıdır. Bankamızın kalite kontrol sistemi müşterimizdir. Bir müşteri şubeden hizmet alıyor. Müşterilerimiz işlem yaptıklarında bankamızın sisteminde görülüyor. Bankamı bu müşterileri sistemde görüyor daha sonra müşteriyi arayıp, gişedeki arkadaşımızın iş tutuşuyla ilgili ne kadar memnunsunuz diye sorularak personelimiz hakkinda gerekli bilgi allyoruz. Bu bilgilendirme sonucunda 1-10 arasında personelimize puan veriliyor. Bankamizın kalite skoru 9-10' dur. O arkadaşımızı raporluyoruz. Anket yapıllyor, memnuniyet düzeyi belirleniyor. \% 70 başarı bekleniyor. $\%$ 70' in altı ise performans notunu etkiliyor. Performans notu personelimizin primini, cebini etkiliyor. Bankamızın performans sistemini müşterimiz belirliyor (YB1)”.

Araştırmanın son bulgusu ise kamu sermayeli bankalar haricindeki diğer tüm bankaların sürdürülebilir rekabette personel ve şube sayısını azaltma, yakın lokasyonda bulunan şubeleri birleştirme, reklam faaliyetlerinde maliyetsiz olan sosyal ağlara yönelme, şube bankacılı̆̆ yerine müş̧terileri dijital kanallara yönlendirme gibi çeşitli uygulamalar ile operasyonel maliyetlerini düşürerek ortalama üzerinde getiri elde ettikleridir. Bulgular sadece kamu sermayeli bankaların bireysel bankacılık uygulamalarında maliyetlerini en aza indirmeye yönelik hiçbir strateji uygulamadıklarını göstermiştir. Özel bankaların aksine personel, araç ve teknoloji kullanımının önemli bir rekabet aracı olduğunu vurgulayan kamu sermayeli bankanın bireysel bankacılık bölge yetkilisi KB1 konu hakkında şu açıklamalarda bulunmuştur: "Maliyetleri düşürme çabası bireysel bankacılık uygulamalarımızda ürün çeşidimizin azalmasına neden olabilir. Bu durum sürdürülebilirliğimizi etkileyecektir. Biliyorsunuz teknolojik değişiklikler bizim sektörümüzde hızlı biçimde ilerliyor. Bunun karşısında modern ve maliyeti azaltan teknolojiye yatırım yapmamak ya da eski teknoloji ile hareket etmek rakiplerimiz karşısında savunmamızı azaltabilir. Biz kamu bankası olarak bu riske girmiyoruz. Bireysel bankacıllk demek personel demek, teknoloji demek. Bireysel bankacılık demek araç kullanımı demek. Müşterinin ayağına Antalya sıcă̆ında takım elbise ile gitmiş bir banka personelimi hayal bile edemiyorum! Hâl böyle olunca en temel kaynaklardaki suyu kesmek bizim bankamızın mantığına hiç uymuyor. Yıllarımızı verdiğimiz bu alanda mevcut müşterilerimizi uzman personelimizle ve yenilenen teknolojimiz ile koruma altına almak, yeni müşterilerimizi de bu yönde kazanmak en temel stratejimiz. Sirf personel ve araba azaltacağlz diye ne personelimizi terletiriz ne de müş̧terilerimizi” (KB1). Araştırmada kamu bankalarının aksine özel ve yabancı 
sermayeli bankaların sürdürüllebilir rekabet üstünlüğü için düşük maliyetli operasyonel faaliyetleri ile performanslarını arttırdığına dair bulgulara ulaşılmışıtı. Yabancı bir bankanın bölge yöneticisi/ satış yöneticisi olan YB1 dijital pazarlama araçlarının şube ve personel sayısı azaltmada ve maliyetleri düşürmede etkili olduğunu vurgulayarak açıklamalarında şu ifadelere yer vermiştir: "Eskiden kimsenin kredi kartı yoktu. Şimdi herkesin var. Bu önemli. Çünkü teknolojinin hızla yayıldı̆̆ını gösteriyor. Internet, cep şubesi gibi kanalları kullanarak verimliliği arttırtyoruz. Böyle olunca biz de kurum olarak \% 60 dijital kanallardan işlem yaptırma hedefi ile hareket ediyoruz. Müssterimizin \% 48'ini bu uygulamaya kaydirlyoruz. Aslında bu durum bizim işimize geliyor. Çünkü şube yoğunluğu fazla olduğunda daha çok personel gerektiğinden maliyet artabiliyor (YBI)".

\section{SONUÇ}

$\mathrm{Bu}$ çalışmanın amacı Türk bankacılık sektöründe faaliyet gösteren kamu, özel ve yabancı sermayeli mevduat bankaların stratejik kaynak olarak bireysel bankacılık uygulamaları açısından ne tür rekabet stratejileri ile sürdürülebilir rekabet sağladıklarının incelenmesidir. Mevcut çalışmanın kuramsal arka planında kaynak temelli okulun ve konumlandırma okulunun birlikte dikkate alındığ bütünleyici bir yaklaşım yer almaktadır. Bütünleyici yaklaşıma göre SRÜ rekabette muhtemel taklit girişimlerine ve endüstrideki muhtemel giriş engellerine rağmen uzun dönemde ortalama üzerinde performans elde etme durumu olarak tanımlanmaktadır. Bu noktadan hareketle araştırmada incelenen işletmelerin sürdürülebilir rekabet üstünlügünde bireysel bankacılık uygulamalarını rekabet stratejilerinde önemli kaynaklar olarak dikkate aldıklarına ve bu kaynakları uzun dönemde ortalama üzerinde getiri elde etmede giriş engelleri olarak algıladıklarına ilişkin bir sonuç elde edilmiştir. Nitekim araştırmada bireysel bankacılık uygulamaları arasında müşteriye özel fiyatlandırma, görsel ve sosyal medya araçlarının kullanımı ve ürün/hizmet sunumuna yönelik süreç yenilikleri bankaların rekabette temel yetenekleri olarak belirlenmiştir. Bulgular bankaların mevcut temel yeteneklerini bütünleştirdikleri rekabet stratejileri ile sektörel düzeyde rekabet gücüne anlamlı bir katkıda bulunduğuna da işaret etmektedir. Sonuç olarak araştırmada tüm bankaların bireysel bankacılık uygulamalarına dayalı algılanan performans düzeyini olumlu yönde en fazla etkileyen üç rekabet stratejisinin sırasıyla fiyat farklılaştırma stratejisi, imaj farklılaştırma stratejisi ve kalite farklılaştırma stratejisi olduğunu göstermiştir. Ayrıca kamu sermayeli bankalar haricindeki diğer tüm bankaların bireysel bankacılık uygulamalarında düşük maliyetli operasyonel faaliyetleri ile uzun dönemli performanslarının arttığı tespit edilmiştir. Özetle bireysel bankacılık uygulamalarının bankalar için temel yetenek olabileceği ve bu yeteneklerin rekabet stratejileri ile sürdürülebilir rekabet üstünlügünü sağlamada dikkat çekici olabileceği söylenebilir.

\section{DEĞERLENDİRME}

Aynı endüstride faaliyet gösteren işletmeler arasında uzun dönemde ortalama üzerinde getiri elde etme (performans sağlama) meselesi alan yazının önemli sorularından biri olduğundan güncel 
tartışmalar sürdürülebilir rekabet üstünlügünü açıklamada endüstri yapısı ve firmaya özgü kaynaklar ilişkisine vurgu yapmaktadır. 21. yüzyıla damgasını vuran yeni ekonomik sistemde diğer tüm işletmeler gibi bankalar da çeşitli kaynak/yetenekler ve rekabet stratejileri ile sürdürülebilir rekabette üstünlük sağlama çabasına girmektedir. Artık yeni ekonomik düzende sektör yönünü işlem maliyetlerini yükselten geleneksel bankacılık yerine bilgi temelli bireysel bankacılık uygulamalarına çevirmiştir (Ulukuş, 2011; capgemini.com, 04.04.2018; thebalance.com, 04.04.2018; hsbc.com, 04.04.2018; pwc.com, 05.04.2018). Bilgi temelli bireysel bankacılık uygulamaları müşterilerin ihtiyaçlarına hızlı ve uygun çözümler yaratmaya olanak sağlayan yenilikçi faaliyetlerin bütünü olarak tanımlanmaktadır (Özkan, 2010; thebalance.com, 04.04.2018; hsbc.com, 04.04.2018; pwc.com, 05.04.2018). Bu faaliyetler müşterilerin ihtiyaçlarını gidermeye yönelik mal ve hizmetlerin alımında finansal destek sağlamadan, ödeme ve para transferi gibi tüm mali işlemlere yönelik her türlü yenilikçi uygulamayı kapsamaktadır. Bankalar bu uygulamaları farklılaştırarak değişen dış çevre koşullarına karşı çeşitli stratejiler ile ortalamanın üzerinde getiri elde etmeye çalışmaktadır. Nitekim bu araştırmada bankalar bireysel bankacılık uygulamalarını rekabet stratejilerinde önemli kaynaklar olarak dikkate almakta ve bu kaynakları uzun dönemde sürdürülebilir performans elde etmede giriş engelleri olarak algılamaktadırlar.

Araştırmada banka yöneticilerinin tamamının sürdürülebilir rekabette işletme performansını en fazla etkileyen rekabet stratejisinin fiyat farklılaştırma olduğuna yönelik ortak algıları tespit edilmiştir. Fiyat farklılaştırma stratejisine yönelik temel bireysel bankacılık uygulamaları ise müşterilerin özellikleri, müşterilerin bağlılık düzeyi), bölgeyi/semti esas alan faaliyetler ve kredibilite oranlarıdır. Araştırmada fiyat farklılaştırma stratejisine yönelik farklı uygulamalar ile rekabet eden bankaların bu sonuçları şaşırtıcı bulunmamıştır. Çünkü Türkiye'de son yıllarda bankalar kredi kayıt bürosundan (KKB) elde ettikleri kredi notuna göre mevcut ya da yeni müşterilerine farklı fiyatlandırma seçenekleri sunmakta olduğu gözlemlenmiştir. Bankaların üst düzeyinde yer alan karar vericiler bu resmi kanal aracılığı ile müşterilerin ödemelerini düzenli yapıp yapmadığını takip ederek özel fiyatlandırma uygulamaları sunmaktadırlar. Araştırmanın bir diğer sonucu bankaların algılanan performans düzeyini etkileyen ikinci rekabet stratejisinin imaj farklılaştırma olduğu ve sürdürülebilir rekabete anlamlı katkısı olduğudur. İmaj farklılaştırma stratejisi en fazla görsel medya araçları ve sosyal medya araçları ile sağlanmaktadır. Teknolojik gelişmeler uzun dönemde hem yeni bankacılık hizmetlerini ortaya çıkarmış hem de bu hizmetlerin tanıtımına yönelik pazarlama araçlarındaki verimliliği arttırmıştır. Başka bir ifade ile bankalar pazarlamaya yönelik yenilik stratejilerini benimsemek zorunda kalmışlardır. Günümüzde bankacılık sektöründe değer yaratımı ürün ve hizmetin sürdürülebilir olarak tercih edilmelerini sağlayabilecek pazarlama yeteneği ile mümkün olabilmektedir.

Araştırmanın bir diğer sonucu kalite farklılaştırma stratejisinin algılanan performans düzeyini etkileyen üçüncü rekabet stratejisi olarak sürdürülebilir rekabete anlamlı katkısı olduğudur. Bankaların sürece yönelik yeniliklerle kaliteyi belirli bir seviyede tutma ya da yükseltme çabası araştırmanın 
önemli sonuçlarından birisidir. Araştırma kapsamında banka yöneticileri özellikle insan kaynakları yönetimine dayalı performans sistemleri ile müşterilerine kaliteli ürün ve hizmet sunduklarını böylece ortalamanın üzerinde getiri elde ettiklerini belirtmişlerdir. Son olarak kamu sermayeli bankalar haricindeki diğer bankaların algılanan performans düzeyini en son sirada etkileyen rekabet stratejisi düşük maliyetli operasyonel faaliyetlerdir. Sonuçlar kamu bankalarının bireysel bankacılık hizmetlerinde maliyet liderliği stratejisine yönelik hiçbir uygulama yapmadıklarını göstermiştir. Güçlü banka imajına zarar vermemek, istihdamı düşürmemek, mevcut müşterilerini kaybetmemek gibi temel nedenler bu durumun gerekçesi olarak açıklanabilir. Aksine araştırmada yer alan özel ve yabancı banka yöneticileri maliyet liderliği stratejisine yönelik banka şube sayılarını azaltma, dijital kanalları ve sosyal ağları yaygınlaştırma yolu ile performans düzeylerini arttırabildiklerini belirtmiştir. İlgili alan yazın ile örtüssen bu bulgu (Acar, 2016; Engin, 2016; Ergin, 2016; Kırcal1, 2016) son y1llarda internet bankacılığının yaygınlaşması ile başlayıp akıllı telefonların günlük hayata girmesi ile devam eden dijital dünyanın sonucu olarak değerlendirilebilir. Türkiye Bankalar Birliği’nin "Türkiye'de Bankacılık Sistemi: Banka, Şube ve Personel Bilgileri" raporuna göre özel ve yabancı bankalarda personel sayısı bir önceki yıla göre \% 2,2 oranında azalmıştır. Bankaların operasyonel maliyetlerini düşürme çabalarının belirtildiği raporda şube bazında her yıl uygulanan harç uygulamasının da bankalara şube açmada caydırıcı rol oynadığı vurgulanmaktadır (tbb.org.tr, 11.06.2017).

Özetle tüm sonuçlar bankaların rekabet stratejileri ile performanslarına ve dolayısyla sürdürülebilir rekabet üstünlüğune anlamlı bir katkı yarattığı biçiminde değerlendirilebilir. Nitekim bu çalışmada bankaların bireysel bankacılık uygulamalarında özellikle fiyat farklılaştırma, imaj farklılaştırma, kalite farklılaştırma ve maliyet liderliği olarak tanımlanan rekabet stratejilerinin performans üzerinde etkili olduğu gözlemlenmiştir. Bu yönüyle araştırmanın rekabet stratejisi ve performans ilişkisinde sürdürülebilir rekabet alan yazınına katkı sağlaması beklenmektedir.

Bireysel bankacılık uygulamalarına özgü temel değişkenlerin (rekabet stratejisi ve performans) ve aralarındaki ilişkilerin belirlenmesine yönelik sınırlı sayıda araştırmaya ve ölçüm araçlarına ulaşılması bu çalışmanın yazına vereceği katkı düzeyinin bir göstergesidir. Keşfedici nitelikte olan bu çalışmanın araştırmacılara ve bankacılık sektöründe karar vericilere sürdürülebilir rekabet gücünün sağlanması hakkında bakış açıları sunacağı düşünülmektedir. Gelecekte benzer bir çalışma ile aynı görüşme formunun kullanılarak sektöre özgü yeni nicel ölçüm araçlarının geliştirilmesinin ve mevcut kuramsal tartışmaların bu ölçüm araçları ile sınanmasının alan yazına yararlı olacağı umulmaktadır.

\section{KAYNAKÇA}

Acar, M. (2016) "Kar Yönetimi Uygulamalarında İhtiyari Tahakkuk İptallerinin Etkisi: Bankacılık Sektörü Üzerine Bir Uygulama”, Doktora Tezi, Hacettepe Üniversitesi Sosyal Bilimler Enstitüsü, İşletme Anabilim Dalı, Ankara. 
Amit, R. ve Schoemaker, P.J. (1993) "Strategic Assets and Organizational Rent", Strategic Management Journal, 14 (1): 33-46. doi.org/10.1002/smj.4250140105

Arslan, R. ve Hotamışlı, M. (2007) "Türk Bankacılık Sisteminde Kurumsal Çevrenin Bankaların Yap1 ve Uygulamaları Üzerinde Oluşturduğu Teşvik ve Kısıtlamalar”, Yönetim ve Ekonomi: Celal Bayar Üniversitesi İktisadi ve İdari Bilimler Fakültesi Dergisi, 14 (1): 195 - 208.

Arslan (2008) “Türk Bankacılık Sisteminde Rekabet Stratejileri ve Yayılım Süreci”, Uşak Üniversitesi Sosyal Bilimler Dergisi 1(2): 125-141.

Barney. J. B. (1986) "Organization Culture: Can it be a Source of Sustained Competitive Advantage?", Academy of Management Review, 11(3): 656-665.

Barney, J. B. (1991) "Firm Resources and Sustained Competitive Advantage", Journal of Management, 17(1): 99-120.

Berg, B. L ve Lune, H. (2015) “Sosyal Bilimlerde Nitel Araştırma Yöntemleri”, H. Aydın, Çeviri Editörü, ISBN: 9786059831116 , Eğitim Kitabevi.

Collis, D. ve Montgomery C.A. (1995) "Competing on Resources: Strategy in the 1990", Harvard Business Review, 73: 118-128.

Conant, J.S., Mokwa, M.P, ve Varadarajan, P.R. (1990) "Strategic Types, Distinctive Marketing Competencies and Organizational Performance: A Multiple Measured- Based Study”, Strategic Management Journal, 11(5): 365-383.

Çağlayan, B. (2017) "Bireysel Bankacılık Hizmetlerinin Rekabet Stratejileri Açısından İçerik Analizi İle İncelenmesi”, Yüksek Lisans Tezi, Akdeniz Üniversitesi, Sosyal Bilimler Enstitüsü, İşletme Anabilim Dal1, Antalya.

Çırpan, B. (2000) “ Kredi Kartları”, Ceren Basım Yayın, Ezgi Kitabevi, 1.Basım, Bursa.

Dess, G. G. ve Davis P.S. (1984) "Porter's Generic Strategies as Determinants of Strategic Group Membership and Organizational Performance", Academy of Management Review, 27(3): 467488.

Dess, G. G ve Robinson R. B. (1984) "Measuring Organizational Performance in the Absence of Objective Measures: The Case of The Privately-Held Firm and Conglomerate Business Unit", Strategic Management Journal, 5: 265-273.

Durmuş Arıcı, E. (2008) "Rekabet Stratejisi, Örgüt Yapısı ve Performans İlişkilerinin Gıda Perakende Sektörü Bağlamında Araştırılması”, Doktora Tezi, Akdeniz Üniversitesi, Sosyal Bilimler Enstitüsü, İşletme Anabilim Dalı, Antalya. 
Engin, F. (2016) "Bankacılık Sisteminde Mali Yapı Analizi”, Yüksek Lisans Tezi, İstanbul Ticaret Üniversitesi, Finans Enstitüsü Finans Anabilim Dalı, Uluslararası Bankacılık ve Finans Bilim Dalı, İstanbul.

Ergin, F. N (2016) "Müşteri İlişkileri Açısından Bankacılıkta Kredi Maliyetlerinin Belirlenmesi”, Yüksek Lisans Tezi, Beykent Üniversitesi, Sosyal Bilimler Enstitüsü İşletme Yönetimi Anabilim Dalı, İstanbul.

Grant, R. (1991) “Porter's Competitive Advantage of Nations: An Assessment”, Journal of Marketing, 12(7): 535-548.

Kırcalı, S. (2016) “Bankacılıkta Kârlılığı Oluşturan Faktörlerin İncelenmesi, Türk Bankacılık Sektörü Verileri Baz Alınarak Sürdürülebilir Kârlılık Konusunun Analiz Edilmesi”, Doktora Tezi, Okan Üniversitesi, Sosyal Bilimler Enstitüsü Bankacılık ve Finans Ana Bilim Dalı, Bankacılık ve Finans Bilim Dalı, İstanbul.

Mintzberg, H. (1988) "Generic Strategies: Toward a Comprehensive Framework", Advances in Strategic Management, 5(1): 1-67.

Özkan, A. (2010) "Bireysel Bankacıllıkta Hizmet Kalitesi ve Müşteri Memnuniyetinin Ölçülmesi: Eskişehir'de Bir Uygulama”, Yüksek Lisans Tezi, Dumlupınar Üniversitesi, Sosyal Bilimler Enstitüsü İktisat Anabilim Dal, Kütahya.

Peteraf, M. (1993) “The Cornerstones of Competitive Advantage: A Resource Based View Strategic Management Journal”, 14 (3): 179-191.

Porter, M. E. (1980) “Competitive Strategy: Techniques for Analyzing Industries and Competitors”, Free Press, USA.

Porter, M. E. (1985) "Competitive Advantage: Creating and Sustaining Superior Performance", Free Press, New York.

Porter, M. E. (2000) "Rekabet Stratejisi: Sektör ve Rakip Analizi Teknikleri”, Sistem Yayınc1lı, İstanbul.

Robinson, R. ve Pearce J.A. (1988) "Planned Patterns of Strategic Behavior and Their Relationship to Business- Unit Performance", Strategic Management Journal, 9(1): 43-60.

Ulukuş, E. (2011) "Bireysel Bankacılıkta Pazarlama Stratejileri”, Yüksek Lisans Tezi, Kadir Has Üniversitesi, Sosyal Bilimler Enstitüsü İşletme Anabilim Dalı, İstanbul.

Venkatraman, N. ve Ramanujam, V. (1986) "Measurement of Business Performance in Strategy Research: A Comparison of Approaches". Academy of Management Review, 11 (4): 801-814.

Venkatraman, N. (1989) "Strategic Orientation of Business Enterprises: The Construct, Dimensionality and Measurement Management Science", 35 (8): 942-962. 


\section{Internet Kaynakları:}

https://www.capgemini.com/service/retail-banking/, (04.04.2018).

https://www.thebalance.com/what-is-retail-banking-3305885, (04.04.2018).

\section{http://www.hsbc.com/careers/explore-our-business/working-in-retail-banking-and-wealth-} management, (04.04.2018).

https://www.pwc.com/gx/en/banking-capital-markets/banking-2020/assets/pwc-retail-banking-2020evolution-or-revolution.pdf , (05.04.2018)

https://muze.isbank.com.tr/Sayfalar/is-bankasi-tarihcesi.aspx, (15.03.2018).

http://www.bkm.com.tr/kronoloji.bkm , (05.01.2018).

https://bkm.com.tr/bkm-hakkinda/bkmyi-taniyin/tarihce/, (05.01.2018).

https://www.haberler.com/turkcell-mobil-imza-ile-internetten-alisveris-haberi/, 2008, (12.02.2018).

www.tbb.org.tr/tr/banka-ve-sektor-bilgileri/istatistiki-raporlar/59, (11.06.2017).

www.tbb.org.tr/tr/bankacilik/banka-ve-sektor-bilgileri/4, (11.06.2017).

www.bankalar.org/bankalar/, (12.06.2017). 